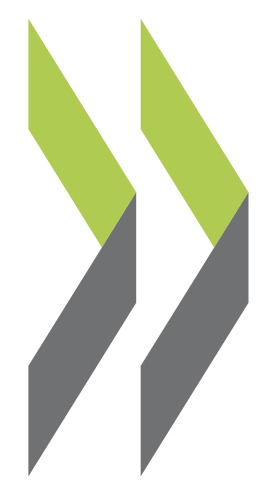

OECD Economics Department Working Papers No. 516

Adapting the Icelandic Education System Hannes Suppanz to a Changing Environment 
Organisation de Coopération et de Développement Economiques

ECONOMICS DEPARTMENT

English text only

ADAPTING THE ICELANDIC EDUCATION SYSTEM TO A CHANGING ENVIRONMENT ECONOMICS DEPARTMENT WORKING PAPERS No. 516

By Hannes Suppanz

All Economics Department Working Papers are available through OECD"s internet web site at www.oecd.org/eco/Working_Papers

JT03213689 


\section{ABSTRACT/RÉSUMÉ}

\section{ADAPTING THE ICELANDIC EDUCATION SYSTEM TO A CHANGING ENVIRONMENT}

This paper reviews Iceland's performance in skills accumulation against the backdrop of a rapidly changing economic environment and discusses directions for further improvements. Since the late 1990s, the government has considerably raised expenditure on education, which is now among the highest in the OECD relative to GDP. Nonetheless, Iceland continues to have one of the largest shares of those in the working age population who have not attained upper secondary or higher qualifications, and educational achievements of 15year olds are not outstanding relative to the country's advanced state of economic development. This is all the more unsatisfactory because spending per student in the compulsory education sector exceeds the OECD mean considerably, even after controlling for differences in per capita GDP. Measures to improve outcomes include curriculum adjustments and an enhancement of teaching evaluation and quality. While ensuring that students acquire a satisfactory basic set of competencies, there is room for reducing the average duration of primary and secondary education, which is quite long by international comparison. In contrast to upper secondary attainment, that for the tertiary sector is above the OECD average, and higher education has to cope with an enormous rise in participation. With a view to maintaining quality in the face of these developments, the government has introduced legislation that is welcome. However, it does not address the issue of tuition fees, which are authorised in the private but not in the public sector.

JEL classification: J20; J21; J22; J23; J24.

Keywords: Education; human capital; education policy; Iceland.

This Working Paper relates to the 2006 OECD Economic Survey of Iceland (www.oecd.org/eco/surveys/iceland).

\section{ADAPTER LE SYSTEME EDUCATIF ISLANDAIS A UN NOUVEAU CONTEXTE}

Ce travail passe en revue les résultats des efforts déployés par l’Islande pour développer les compétences de sa population dans un contexte économique en mutation rapide, et examine la voie à suivre pour progresser encore dans ce domaine. Depuis la fin des années 90, les pouvoirs publics ont sensiblement augmenté les dépenses d'éducation, qui figurent aujourd'hui parmi les plus élevées des pays de l’OCDE par rapport au PIB. Toutefois, l'Islande enregistre toujours l'une des plus fortes proportions de personnes d'âge actif qui n'ont pas achevé le deuxième cycle de l'enseignement secondaire, et les acquis scolaires des jeunes de 15 ans ne sont pas exceptionnels compte tenu du stade avancé de développement économique du pays. Cette situation est d'autant moins satisfaisante que les dépenses par élève dans le secteur de l'enseignement obligatoire sont très supérieures à la moyenne des pays de l'OCDE, même une fois prises en considération les différences de PIB par habitant. Les mesures requises en vue d'y remédier consistent, entre autres, à ajuster les programmes d'enseignement et à renforcer l'évaluation de l'enseignement et la qualité de ce dernier. Il est possible, tout en veillant à ce que les élèves acquièrent un ensemble suffisant de compétences de base, de réduire la durée moyenne de la scolarité dans l'enseignement primaire et secondaire, qui est assez longue par rapport aux autres pays. A la différence de ce que l'on observe dans le cas du deuxième cycle du secondaire, les personnes qui ont fait des études supérieures sont proportionnellement plus nombreuses que la moyenne des pays de l'OCDE et l'enseignement supérieur doit faire face à une énorme augmentation de ses effectifs. Afin que cette évolution ne soit pas préjudiciable à la qualité, les pouvoirs publics ont adopté des textes de loi que l'on peut saluer. Toutefois, ceuxci n'abordent pas le problème des droits de scolarité, dont le prélèvement est autorisé dans le secteur privé mais non dans le secteur public.

Classification JEL : J20; J21; J22; J23; J24.

Mots clés : Education; capital humain; politique d'éducation; Islande.

Ce document de travail se rapporte à l'Etude économique de l'OCDE de l'Islande 2006 (www.oecd.org/eco/etudes/islande).

\section{Copyright OECD, 2006}

Application for permission to reproduce or translate all, or part of, this material should be made to: Head of Publications Service, OECD, 2 rue André-Pascal, 75775 Paris Cedex 16, France. 


\section{TABLE OF CONTENTS}

The changing structure of the economy requires adjustments in the area of human resources ....................5

Expenditure on education has been raised considerably ..........................................................................

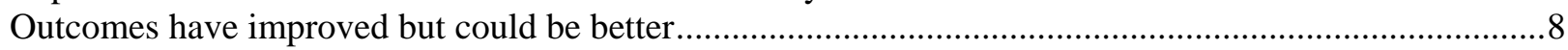

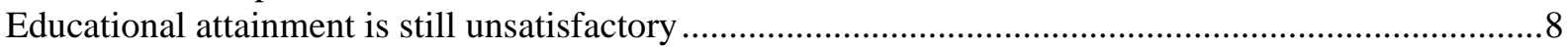

Educational achievement is affected by poor results in rural areas.....................................................11

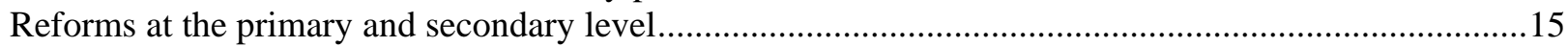

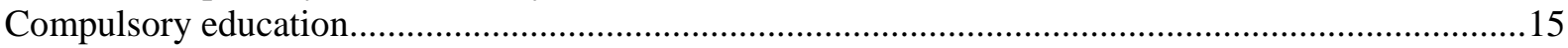

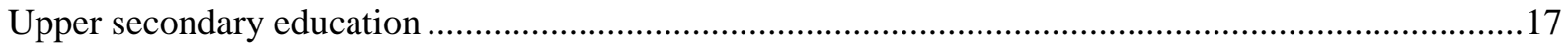

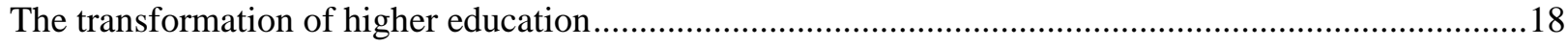

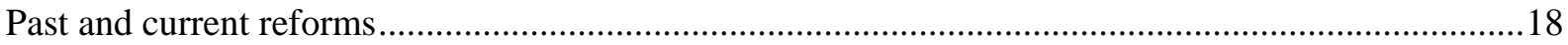

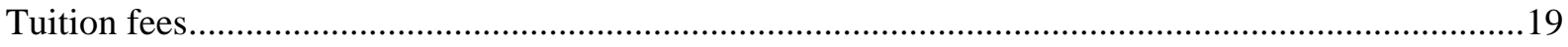

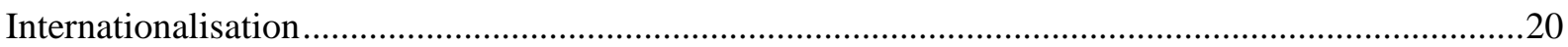

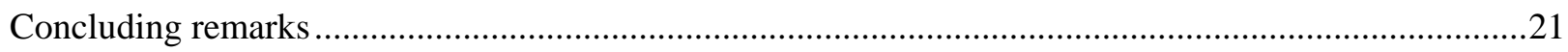

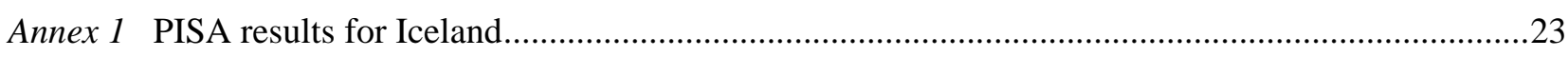

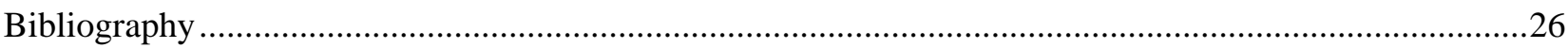

\section{Tables}

1. Labour market outcomes and educational attainment.....................................................................10

2. Factors influencing 2003 PISA scores in selected OECD countries..................................................13

3. The performance of Icelandic students in mathematics in PISA 2003 by geographical area ................14

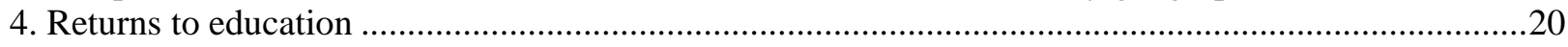

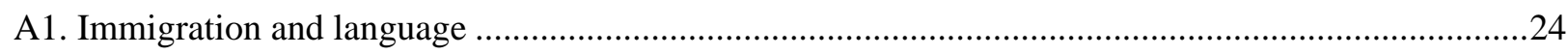

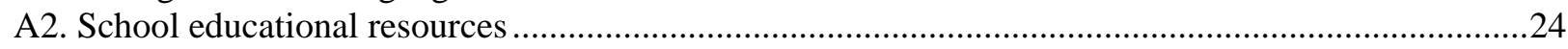

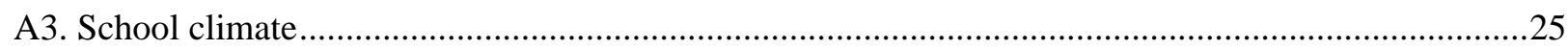

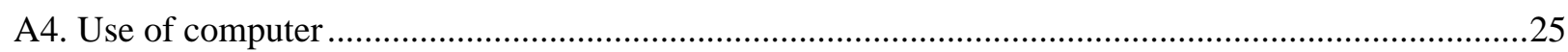

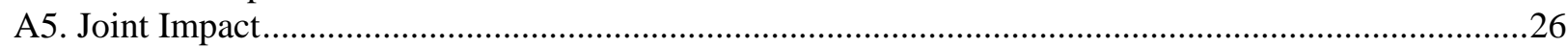

\section{Figures}

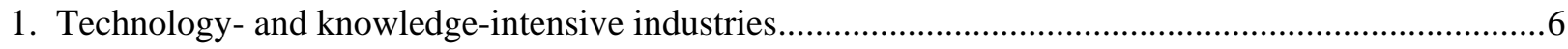

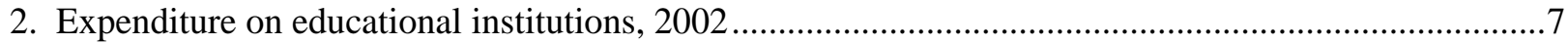

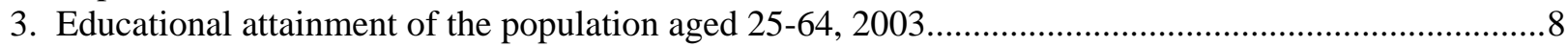

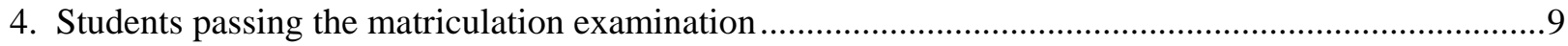

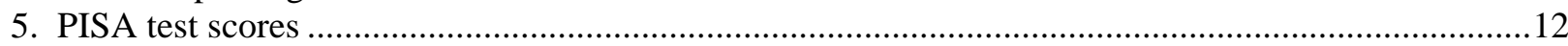

6. Icelandic students at the tertiary level at home and abroad ...........................................................21

\section{Boxes}

Box 1. Recommendations regarding human resource development...... 
ECO/WKP(2006)44 
ECO/WKP(2006)44

\title{
Adapting the Icelandic education system to a changing environment
}

\author{
by Hannes Suppanz ${ }^{1}$
}

\section{The changing structure of the economy requires adjustments in the area of human resources}

1. The Icelandic economy has changed markedly over the last few decades. The importance of the primary sectors of agriculture and fisheries has declined considerably. Certainly, the latter still dominates the country's exports, at least until production in the new aluminium plants comes on stream. But, as noted in the previous chapter, financial intermediation now employs more people than fisheries. Over seven out of ten workers are already employed in the service sector. At the same time, structural reforms have transformed the economy and have made it more global and competitive. As it becomes more internationalised and less dependent on primary activities, demand for a highly educated workforce will increase significantly. The present (and probably continuing) vast expansion of the aluminium sector reflects the authorities' view that Iceland should diversify its export base by diminishing its dependence on fisheries, while simultaneously taking advantage of its wealth of renewable energy resources. If wellmanaged, this shift will raise national income, but ultimately economic success and a continuously rising standard of living will depend on the country's skills base and the ability of its workforce to respond to changing market needs. Investment in, and improvement of, human capital is crucial to further developing fast-growing activities, such as technology and knowledge-intensive industries, whose share of total value added -- albeit rising -- is still quite low by international comparison (Figure 1).

1. This paper is based largely on material from the OECD Economic Survey of Iceland published in August 2006 under the authority of the Economic and Development Review Committee (EDRC). The authors would like to thank Val Koromzay, Andrew Dean, Patrick Lenain, Paulo Santiago and Francesco Pedro for valuable comments on earlier drafts. The paper has also benefited from discussions with numerous Icelandic experts, including from the government. Special thanks go to Sylvie Foucher-Hantala for technical assistance and to Chrystyna Harpluk and Deirdre Claassen for technical preparation. 
Figure 1. Technology- and knowledge-intensive industries

Share of total gross value added, 2002
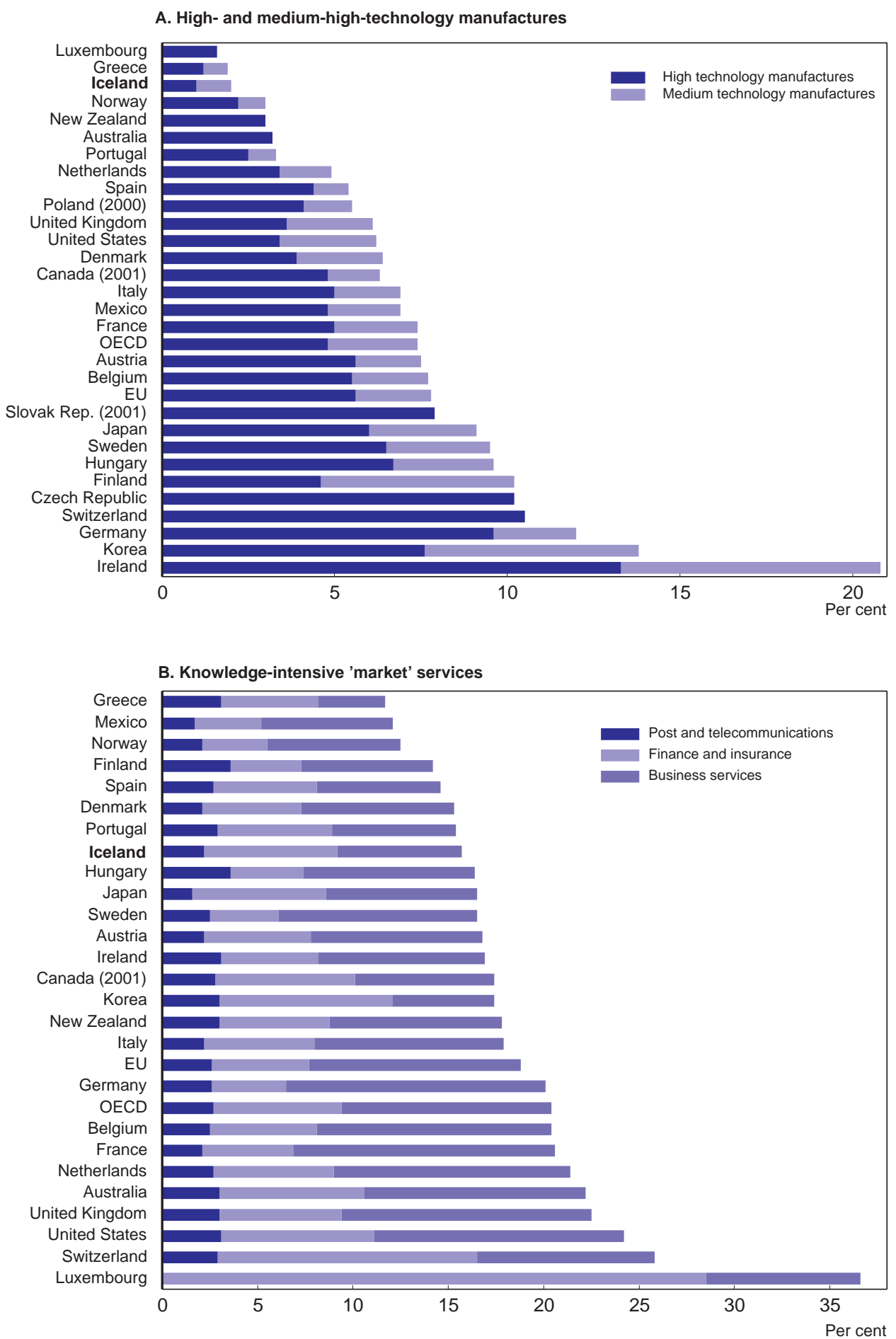

Source: OECD, Science, Technology and Industry Scoreboard 2005. 


\section{Expenditure on education has been raised considerably}

2. The authorities have increasingly stressed the importance of human resource development for Iceland's capability to diversify and its future economic performance. Accordingly, public spending on education -- which accounts for the bulk of total expenditure on educational institutions -- has been increased considerably. By 2002, the last year for which comparable data are available (OECD, 2005a), Iceland's total education spending had reached 71/2 per cent of GDP, about 2 percentage points more than ten years earlier and the highest level in the OECD (Figure 2, Panel A). Since then, it seems to have grown broadly in line with national income. Given Iceland's relatively young population, expenditure per student is less outstanding, but still exceeds the OECD mean by more than one-tenth (Figure 2, Panel B). This differential largely reflects very high expenditure on compulsory education, with per student spending at the primary and lower secondary level surpassing the OECD mean by one-third and one-fifth, respectively. Educational expenditure per student at the compulsory level in relation to GDP per capita -- which can be interpreted as the resources spent on young people relative to a country's ability to pay -- exceeds the OECD mean by about $5 \%$.

Figure.2. Expenditure on educational institutions, 2002

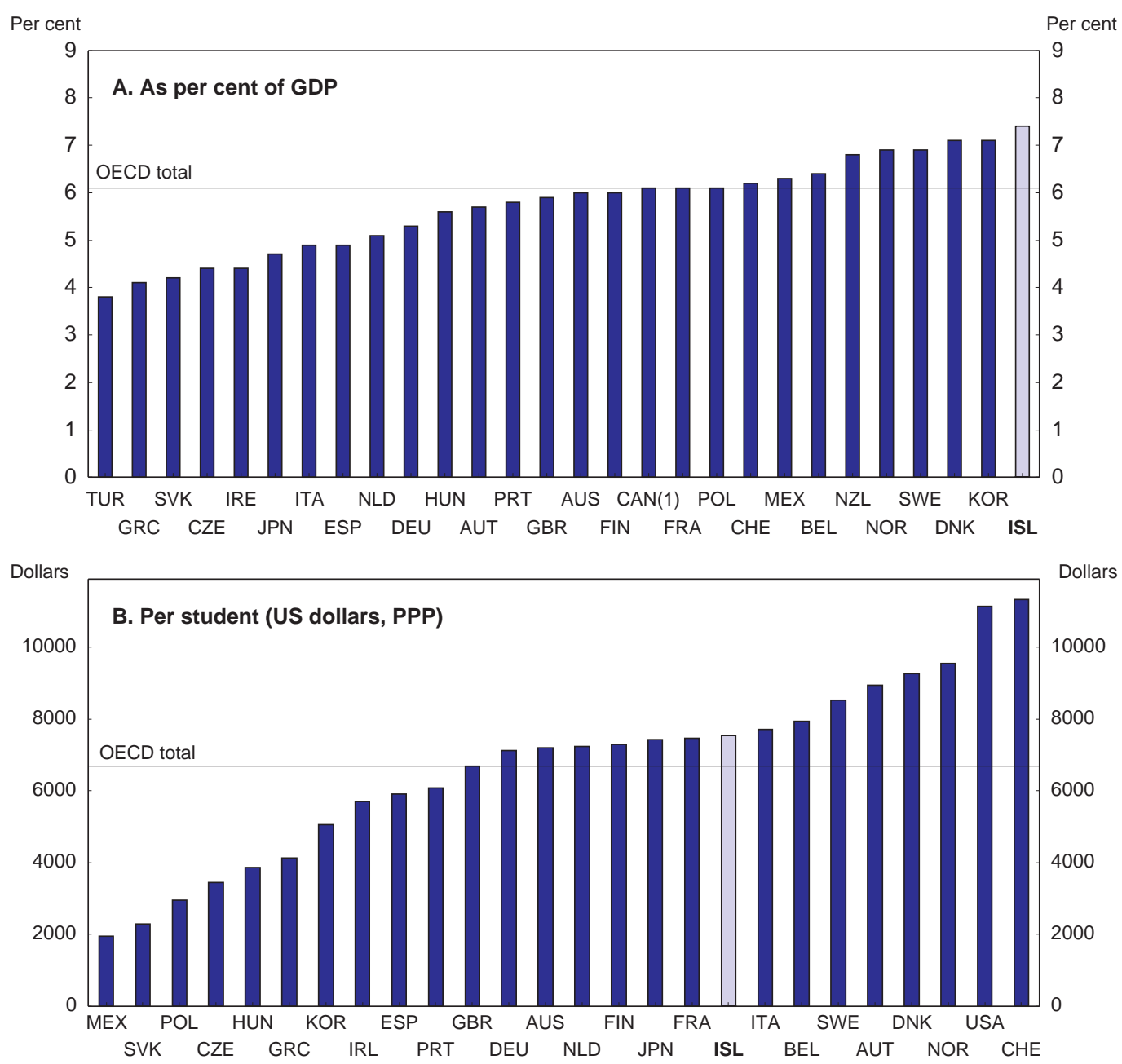

1. Data refer to 2001.

Source: OECD, Education at a Glance, 2005. 


\section{Outcomes have improved but could be better}

\section{Educational attainment is still unsatisfactory}

3. Despite increased funding, educational attainment has remained low by international comparison. Iceland's workforce continues to be characterised by a gap in the skill spectrum between the low skilled and highly skilled. Both the share of those with only compulsory education (more than one-third) and those with tertiary education (more than a quarter) is higher than on average in the OECD (Figure 3). This situation has not changed fundamentally despite a rise in enrolment at the upper secondary level by more than $10 \%$ in the five years to 2004 (at the same time, the number of students at the higher education level increased by more than half). Although the enrolment rate of 16 -year olds has exceeded $90 \%$, it drops fast, especially in rural areas. For 17-year olds the average rate is already 10 percentage points lower, and for 18-year olds some 18 points lower. In some rural areas the decline in the first and second years of upper secondary education is as much as 15 and 28 percentage points, respectively. The favourable labour market situation plays a role, together with a flexible education system that allows students to quit school temporarily. Moreover, the relatively high dropout rate may in part reflect the emphasis placed on the academic line of studies rather than vocational training. Only about one-third of upper secondary school students opt for such a track (as compared with about one-half in the OECD), and the number of those graduating with vocational qualifications has not grown during the past decade, even falling in many trades (Ministry of Education, 2005). By contrast, the number of students passing the matriculation examination (which allows university entry) as a percentage of those aged 20 (when students generally graduate from upper secondary education) has increased, though mainly for females (Figure 4). For young males, the matriculation rate is still very low, at around $45 \%$, and not much above its previous peak in the late 1990s.

Figure 3. Educational attainment of the population aged 25-64, 2003

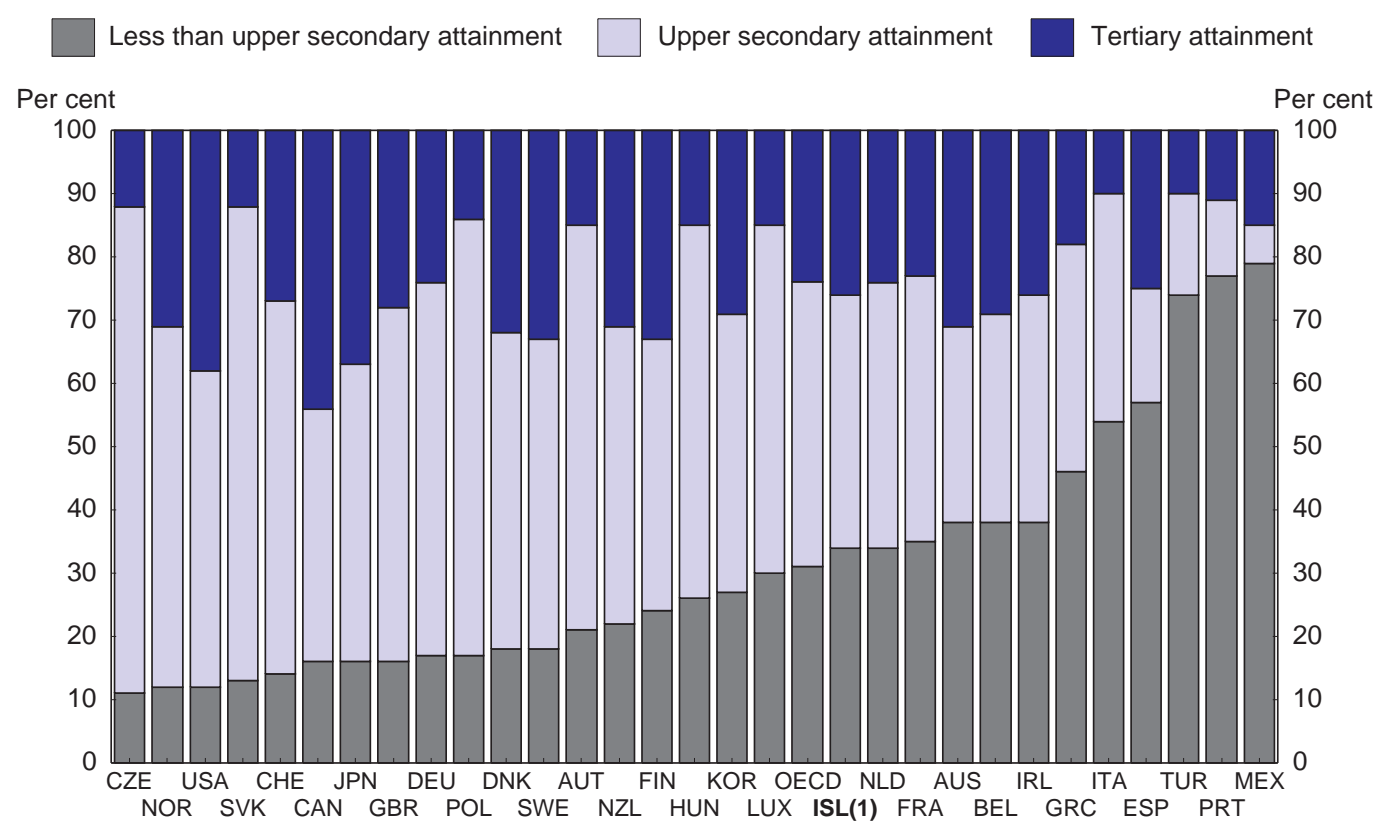

1. Data refer to 2002.

Source: OECD, Education at a Glance, 2005. 
Figure 4. Students passing the matriculation examination

As percentage of 20-year-olds

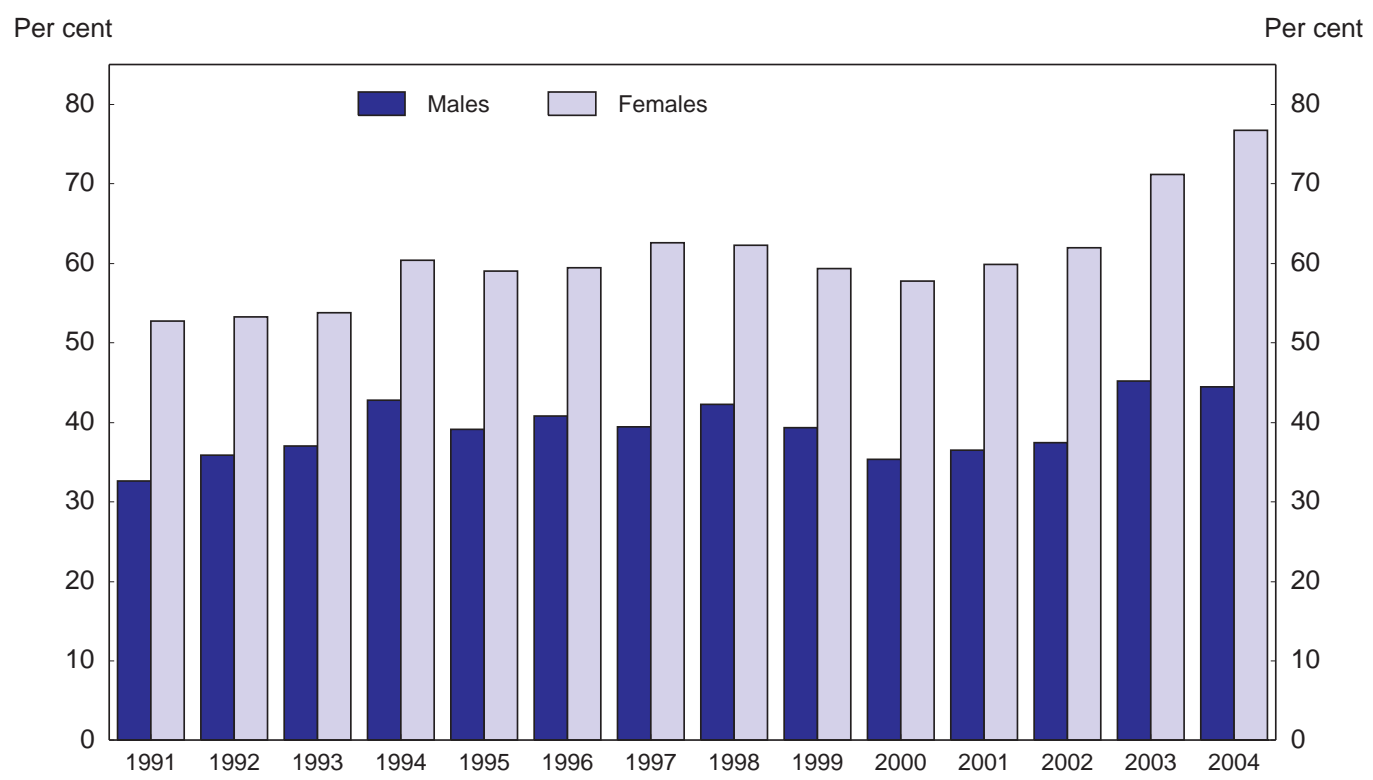

Source: Statistics Iceland (2005), Statistical Yearbook.

4. It may be asked whether the persistent "skills gap" should be a matter of concern. Indeed, despite its changing structure, the economy is still relatively resource-based and labour intensity in primary sectors is rather high. This has arguably had a dampening effect on the demand for skilled labour. At the same time, the development of a welfare society has stimulated the creation of jobs that require a university education. Moreover, incentives for the low skilled to upgrade their skills are weak. In stark contrast to other OECD countries, the employment rate of those who have attained upper secondary qualifications is hardly different from that for workers with only compulsory schooling (Table 1). For the latter, compared to the OECD benchmark, the probability to be employed is, respectively, one-quarter and two-thirds higher for males and females. A significant rise in employment rates is only achieved by those with tertiary qualifications. The picture is similar for unemployment rates, although in this respect there is a more systematic (negative) relationship with educational attainment. However, the proportion of university graduates among the unemployed has tended to rise in recent years, possibly indicating some mismatch between job creation and skill development (Ministry of Education, 2005). There is a serious hazard in projecting such a distribution forward, however. At a minimum, maintaining high employment levels for the less skilled will -- in a globalising world economy -- put increasing strain on the relative wage such people can expect to earn; these same pressures are likely to increase the skill premium in wages for the higher educated. 
Table 1. Labour market outcomes and educational attainment

2002

\begin{tabular}{|c|c|c|c|c|c|c|c|c|}
\hline & Iceland & $\begin{array}{l}\text { OECD } \\
\text { mean }\end{array}$ & $\begin{array}{l}\text { Iceland's } \\
\text { rank }\end{array}$ & $\begin{array}{l}\text { Iceland as a \% } \\
\text { of OECD mean }\end{array}$ & Iceland & $\begin{array}{l}\text { OECD } \\
\text { mean }\end{array}$ & $\begin{array}{l}\text { Iceland's } \\
\text { rank }\end{array}$ & $\begin{array}{l}\text { Iceland as a \% of } \\
\text { OECD mean }\end{array}$ \\
\hline & \multicolumn{4}{|c|}{$\begin{array}{c}\text { Number of } 25 \text { to } 64 \text {-year olds in employment as a } \\
\text { percentage of the population aged } 25 \text { to } 64\end{array}$} & \multicolumn{4}{|c|}{$\begin{array}{c}\text { Number of } 25 \text { to } 64-y e a r \text { olds who are unemployed as } \\
\text { a percentage of the population aged } 25 \text { to } 64\end{array}$} \\
\hline \multicolumn{9}{|c|}{ Lower secondary education } \\
\hline Males & 92 & 73 & $2 / 30$ & 126 & 3.0 & 6.9 & $25 / 30$ & 43 \\
\hline Females & 82 & 49 & $1 / 30$ & 167 & 2.7 & 5.1 & $23 / 30$ & 53 \\
\hline \multicolumn{9}{|c|}{ Upper-secondary education (ISCED 3A) } \\
\hline Males & 91 & 83 & $1 / 29$ & 110 & 2.7 & 4.1 & $22 / 29$ & 66 \\
\hline Females & 84 & 66 & $1 / 29$ & 127 & 2.5 & 4.1 & $20 / 29$ & 61 \\
\hline \multicolumn{9}{|c|}{ Post-secondary non-tertiary education } \\
\hline Males & 95 & 85 & $1 / 16$ & 112 & 1.8 & 4.0 & $11 / 16$ & 45 \\
\hline Females & 85 & 73 & $2 / 16$ & 116 & 1.5 & 4.6 & $14 / 15$ & 33 \\
\hline \multicolumn{9}{|c|}{ Tertiary education, Type B } \\
\hline Males & 95 & 88 & $2 / 25$ & 108 & 2.8 & 3.5 & $17 / 25$ & 80 \\
\hline Females & 92 & 76 & $1 / 25$ & 121 & 1.0 & 3.0 & $21 / 24$ & 33 \\
\hline \multicolumn{9}{|c|}{ Tertiary education, Type A and advanced research programmes } \\
\hline Males & 98 & 89 & $1 / 30$ & 110 & 1.2 & 2.9 & $27 / 30$ & 41 \\
\hline Females & 94 & 78 & $1 / 30$ & 121 & 1.7 & 3.3 & $24 / 30$ & 52 \\
\hline
\end{tabular}

Source: OECD (2006). 
5. Against this backdrop, it is worrying that Iceland is falling behind in the middle part of the skill distribution. The share of the population that has attained at least upper secondary education has grown much less than abroad so that the qualification gap relative to the OECD average is greater for young Icelanders than for older ones. Recent research suggests that the returns of human capital in terms of higher economic growth are more sensitive to the average skills of the entire population, as opposed to the share of individuals who acquire high levels of skills, and that the proportion of individuals who have very low levels of literacy and numeracy acts as a drag on growth (Coulombe et al., 2004).

\section{Educational achievement is affected by poor results in rural areas}

6. Considering the high per student expenditure on compulsory education in Iceland, the PISA study shows modest achievements at the level of lower secondary school. Finland, the best performer, has on average around $10 \%$ better test scores, despite spending about $20 \%$ less per student on compulsory schooling (OECD, 2004). In 2003, Icelandic students at age 15 performed better than the OECD average on the mathematics scale, but test scores on the reading scale dropped below the OECD benchmark compared to the results in 2000, while those on the science scale remained slightly sub-par (Figure 5). This is in line with longer-term developments. Since the 1990s (OECD, 1997), performance in mathematics has improved, moving from below to above the OECD average, science scores have remained broadly stable, and reading literacy has tended to deteriorate.

7. An analysis of the 2003 PISA results (Table 2) shows that the social background has a significant positive effect on outcomes in Iceland as generally elsewhere, although the impact is the weakest among OECD countries. Conversely, by international comparison, gender has the strongest influence, with boys systematically underperforming across all test fields. Iceland is the only member country where female students score better in mathematics than male ones (OECD, 2004). Contrary to most other countries, grade does not play a role because the Icelandic system does not practice any student selection (in terms of streaming or grade repetition) so that virtually all students in the sample are at the same grade. An immigration background and the language spoken at home have a significant negative impact on test results, but not independent from each other. "Soft" variables such as the school climate and student/teacher relations matter more than indicators of the school infrastructure and quality of educational resources. Computer resources at school are not found to make a difference, while computer access at home -- which is very high in Iceland (OECD, 2005b) -- has a significant positive impact (provided it is used for educational purposes). The equation that best explains the Icelandic test scores includes, in addition to the basic variables gender and parents' occupational status, variables for student/teacher relations and computer facilities at home (see Annex 1). 
Figure 5. PISA test scores
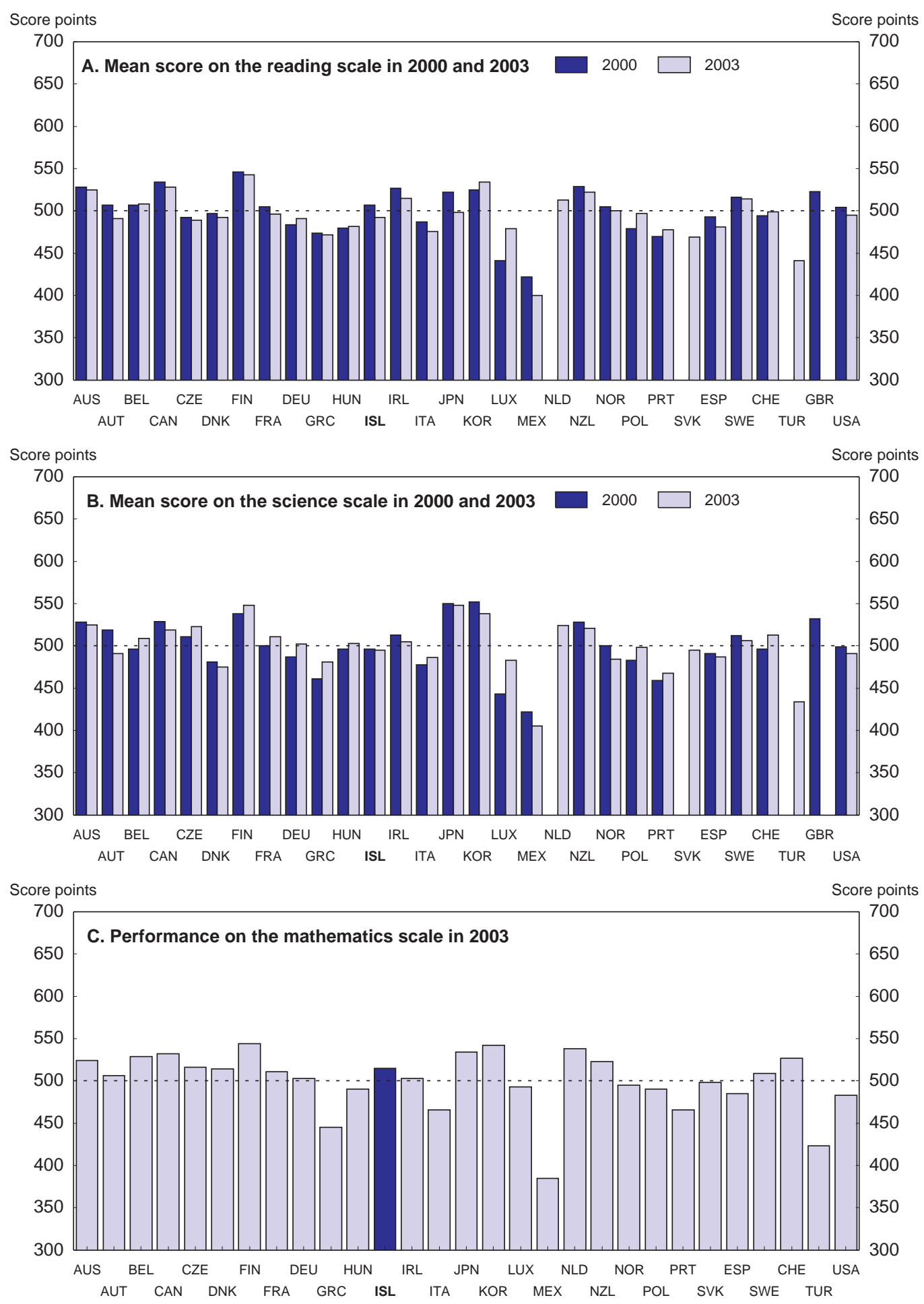

Source: OECD Factbook 2005. 
ECO/WKP(2006)44

Table 2. Factors influencing 2003 PISA scores in selected OECD countries

\begin{tabular}{|c|c|c|c|c|c|c|c|c|}
\hline & Grade & Gender & $\begin{array}{l}\text { Occupational } \\
\text { status of } \\
\text { parents } \\
\left({ }^{\star} 100\right)\end{array}$ & $\begin{array}{l}\text { Immigration } \\
\text { status }\end{array}$ & $\begin{array}{l}\text { Ability } \\
\text { grouping }\end{array}$ & $\begin{array}{c}\text { Extra- } \\
\text { curriculum } \\
\text { school } \\
\text { activities } \\
\end{array}$ & $\mathrm{R}^{2}$ & $\begin{array}{c}\text { Number of } \\
\text { observations }\end{array}$ \\
\hline Australia & 0.74 & -0.13 & 3.45 & -0.13 & ns & 0.17 & 0.16 & 11661 \\
\hline Austria & 0.64 & 0.23 & 2.65 & -0.41 & -0.91 & 0.63 & 0.36 & 4308 \\
\hline Belgium & 1.29 & 0.06 & 2.62 & -0.45 & 0.21 & 0.71 & 0.44 & 8121 \\
\hline Canada & 1.06 & ns & 2.67 & -0.13 & ns & 0.04 & 0.16 & 24995 \\
\hline Czech Republic & 0.81 & ns & 3.99 & Ns & -0.22 & 0.17 & 0.18 & 5987 \\
\hline Denmark & 1.10 & ns & 3.14 & -0.60 & ns & ns & 0.14 & 3728 \\
\hline Finland & 0.97 & -0.28 & 2.74 & -0.66 & ns & ns & 0.12 & 5655 \\
\hline Germany & 0.95 & 0.14 & 2.71 & -0.45 & -0.52 & 0.47 & 0.42 & 3741 \\
\hline Greece & 0.69 & ns & 3.11 & Ns & Ns & 0.31 & 0.19 & 4126 \\
\hline Hungary & 0.83 & -0.07 & 4.41 & Ns & 0.09 & 0.36 & 0.28 & 4247 \\
\hline Iceland & ns & -0.57 & 1.87 & -0.65 & 0.05 & -0.18 & 0.06 & 2840 \\
\hline Ireland & 0.43 & -0.04 & 4.05 & Ns & ns & 0.23 & 0.17 & 3283 \\
\hline Italy & 1.06 & ns & 2.66 & 0.11 & -0.30 & 0.38 & 0.22 & 10928 \\
\hline Japan & ns & ns & 2.53 & -0.53 & -0.36 & 0.28 & 0.07 & 4143 \\
\hline Korea & 0.62 & ns & 2.50 & Ns & 0.12 & 0.57 & 0.12 & 5197 \\
\hline Luxembourg & 1.05 & ns & 2.70 & -0.34 & -0.28 & 0.25 & 0.33 & 3682 \\
\hline Netherlands & 1.07 & 0.12 & 2.57 & -0.46 & -0.21 & 1.13 & 0.40 & 3532 \\
\hline New Zealand & 1.17 & -0.06 & 3.59 & -0.22 & -0.08 & ns & 0.16 & 3644 \\
\hline Norway & 0.76 & -0.22 & 3.58 & -0.57 & -0.12 & ns & 0.12 & 3779 \\
\hline Poland & 1.98 & ns & 4.33 & Ns & ns & -0.06 & 0.22 & 4207 \\
\hline Portugal & 1.35 & 0.17 & 2.31 & -0.42 & ns & -0.10 & 0.52 & 4428 \\
\hline Slovak Republic & 0.41 & ns & 4.01 & -0.79 & -0.15 & 0.24 & 0.18 & 6959 \\
\hline Spain & 1.67 & ns & 2.19 & -0.21 & Ns & 0.09 & 0.32 & 9678 \\
\hline Sweden & 1.30 & -0.15 & 3.17 & -0.69 & 0.06 & 0.09 & 0.17 & 4376 \\
\hline Switzerland & 0.81 & ns & 2.18 & -0.74 & -0.44 & 0.75 & 0.33 & 7684 \\
\hline Turkey & 0.53 & ns & 3.35 & Ns & 0.43 & 0.65 & 0.27 & 4213 \\
\hline United Kingdom & 0.32 & -0.21 & 4.07 & -0.15 & ns & 0.07 & 0.14 & 8349 \\
\hline United States & 0.67 & ns & 3.26 & -0.26 & ns & ns & 0.16 & 4192 \\
\hline
\end{tabular}

Note: This table shows the coefficients estimated for each country individually by regressing the explanatory variables shown against 2003 PISA scores, which are summarised by the first principal component of the four PISA test scores (mathematics, science, reading, problem solving) as the dependent variable. France and Mexico are not included due to missing observations of school level data.

Source: PISA 2003, Secretariat calculations.

8. $\quad$ A recent study (Olafsson et al., 2006) draws attention to the fact that the PISA 2003 results for mathematics are strongly influenced by poor achievements of male students in rural areas (Table 3). Girls in rural areas perform no worse than girls in urban areas and even have higher average scores in some cases. Significant gender differences are only observed in rural Iceland, with the exception of the quantity subscale, where the difference is marked everywhere in the country. A possible explanation for these outcomes is the so-called "Jokkmokk" effect (a term from Sweden), according to which the boys in rural areas would be attracted by well paid jobs and away from learning, while girls' lack of similar opportunities would steer them towards pursuing their studies. What is puzzling, however, is that in reading literacy there is no significant difference in the performance gap in favour of girls between rural and urban areas. To investigate the validity and stability of the PISA mathematics results, the above study compared them with the Icelandic National Examination for $10^{\text {th }}$ graders, which allows yearly comparisons, and broke down the rural region into smaller areas for a more detailed analysis. It found that the regional and gender difference in PISA is replicated by Icelandic examination results, but that the latter fluctuate considerably from year to year and region to region. A drawback of the national examinations at the end of compulsory education is that they are optional (see below), while the PISA sample covers the vast majority of the student population. In any case, the 2003 findings deserve attention, although it remains to be seen whether they will be reproduced in the current PISA round. 
Table 3. The performance of Icelandic students in mathematics in PISA 2003 by geographical area

\begin{tabular}{|c|c|c|c|c|c|c|c|c|c|c|c|}
\hline & & Mathematics & SE & $\begin{array}{l}\text { Space \& } \\
\text { shape }\end{array}$ & SE & $\begin{array}{l}\text { Change and } \\
\text { relationships }\end{array}$ & SE & Uncertainty & SE & Quantity & SE \\
\hline \multirow[t]{3}{*}{ Reykjavik } & Girls & 526 & 3.8 & 512 & 3.9 & 519 & 3.7 & 536 & 4.1 & 532 & 3.8 \\
\hline & Boys & 518 & 4.1 & 505 & 4.2 & 512 & 4.3 & 538 & 3.8 & 509 & 4.3 \\
\hline & Total & 522 & 2.8 & 509 & 2.8 & 515 & 2.7 & 537 & 2.5 & 520 & 2.7 \\
\hline \multirow[t]{3}{*}{ Outer Reykjavik area } & Girls & 524 & 4.7 & 513 & 4.9 & 514 & 5.1 & 535 & 5.0 & 531 & 5.7 \\
\hline & Boys & 516 & 4.1 & 505 & 4.6 & 515 & 4.9 & 535 & 4.8 & 508 & 4.8 \\
\hline & Total & 520 & 2.8 & 509 & 3.0 & 514 & 3.0 & 535 & 2.8 & 519 & 3.1 \\
\hline \multirow[t]{3}{*}{ Rural } & Girls & 520 & 3.4 & 509 & 3.8 & 511 & 3.8 & 527 & 3.8 & 523 & 3.6 \\
\hline & Boys & 496 & 3.5 & 485 & 3.5 & 494 & 3.7 & 508 & 3.5 & 488 & 3.7 \\
\hline & Total & 507 & 2.6 & 497 & 2.6 & 502 & 2.6 & 517 & 2.6 & 505 & 2.8 \\
\hline \multirow[t]{3}{*}{ Total } & Girls & 523 & 2.2 & 511 & 2.3 & 514 & 2.3 & 532 & 2.4 & 528 & 2.3 \\
\hline & Boys & 508 & 2.3 & 496 & 2.4 & 505 & 2.4 & 524 & 2.5 & 500 & 2.5 \\
\hline & Total & 515 & 1.4 & 504 & 1.5 & 510 & 1.4 & 528 & 1.5 & 513 & 1.5 \\
\hline
\end{tabular}

Source: Olafsson et al., (2006). 
ECO/WKP(2006)44

\section{Reforms at the primary and secondary level}

9. During the past decade, Iceland's educational system has undergone major modifications. In the middle of the 1990s, legislation governing the system was changed for every school level. Although some of the reforms were fully enacted only in recent years, new ones are already being prepared. The following sections examine to what extent the institutional setup may help explain the educational outcomes reviewed above and whether envisaged reforms are likely to address the identified shortcomings.

\section{Compulsory education}

10. A major reform implemented in the mid-1990s was the devolution of responsibility for compulsory education (until the age of 16) to the municipalities in return for a greater share of personal income tax revenues. In addition, a special fund was set up in order to offset the effects of different per capita income levels and school sizes. Municipalities now decide about the establishment and running of compulsory schools and bear the cost of their construction and operation (teaching, administration, but not educational materials). The central government's role is limited to monitoring the implementation of laws and regulations (including national curriculum guidelines), the publication of educational materials and the organisation of co-ordinated national examinations. This reform, which became effective in August 1996, reflected a general trend in Iceland towards decentralisation and the presumption that increased local autonomy would have positive effects on educational performance.

11. The pick-up in Iceland's educational expenditure-to-GDP ratio coincided with the transfer of responsibility for compulsory schooling to the municipalities. Outlays at the local government level (which also includes part of the cost of pre-school education) account for almost two-thirds of the rise in the ratio in the six years to 2003, although student numbers at the other levels of education that are financed by the central government increased much more. The rise in outlays reflects a strong expansion of teaching personnel: from 1998 to 2005, the number of teachers in compulsory schooling grew by 22\% (37\% in terms of full-time equivalents). With student numbers rising by only $5 \%$ over the same period, the pupil-toteacher ratio fell to below 10. In terms of full-time equivalents, it is just over 10, as compared to an OECD mean of over 15. Although there is no longer a legal ceiling, the average class size has declined and is the third-lowest in the OECD. While the strong rise in teaching staff is the major factor boosting labour costs, substantial wage increases have also played a role. To some extent, an adjustment was required since a lengthening of the school year, which used to be extremely short, limited the possibility for teachers to have a second job. By 2003, teachers' pay was still quite low by international comparison (though some municipalities offer various fringe benefits such as inexpensive housing). However, the gap vis-à-vis the OECD average is much smaller if salaries are related to the actual teaching time. With the latter only about one-third of the total statutory working time, net teaching time at the compulsory level in Iceland is among the lowest in the OECD. A re-organisation of teachers' working time combined with an increase in pupil/teacher ratios and class sizes would entail resource and cost savings that would allow the employment of a more qualified teaching staff and might, in the end, have a positive effect on educational achievements.

12. Relatively low pay may have affected average teacher qualification. PISA 2000 found that the percentage of students in schools with teachers possessing a third level (ISCED5A) qualification in the language of instruction was almost 50 points lower than on average in the OECD (OECD, 2005c). This might help explain the downtrend in reading literacy scores to below the OECD average. According to PISA 2003, principals evaluated the share of students in schools where instruction is hindered by a shortage of qualified science and mathematics teachers at about one-third, while it was not much above zero in countries like Korea and Finland (OECD, 2004). As to the lack of experienced teachers, the situation was less severe but still much worse than in the best performing countries. Although the econometric analysis summarised above did not find a significant influence of the proportion of licensed 
teachers on educational achievements (in addition to other factors such as the socio-economic background), the strong regional differences in this respect are worth mentioning. While in the capital area more than $90 \%$ of the compulsory school teachers have a licence, this share can be as low as $60 \%$ in some rural areas. In principle, employing a teacher without full qualification as specified by law is not permitted. Such a person can only be (temporarily) hired when no fully qualified teacher is available. In order to ensure a high quality of education, this rule needs to be adhered to more strictly, although this has to be complemented by incentives to attract more qualified teachers to rural areas (OECD, 2005d). A committee is currently reviewing teacher education and training with a view to making proposals for improvements in this area. While any reforms that would lead to an increased supply of qualified teachers are welcome, it is clear that, to a large extent, the shortage of qualified personnel reflects the unusually low pupil/teacher ratio and small average class size. There is international evidence that the expansion of the teaching force in order to staff a policy of smaller classes is not only unlikely to lead to significant learning gains but can also lead to a decline in the in the average quality of new teaching recruits (OECD, 2005d).

13. The success of the education system in Finland, a leader in the PISA scores, has been attributed, among other things, to school autonomy, curriculum diversity and the absence of student selection (Schleicher, 2006). With the reform in the mid-1990s, the Icelandic system has moved significantly in this direction. Teachers are appointed and schools are run by local authorities. Although the national authorities issue curriculum guidelines, there is considerable room for latitude. Schools devise their own study programmes within the framework thus laid down and may determine the balance and time budget between subjects (although the national guidelines indicate the number of teaching hours to be devoted to each subject for each school year). There is no selection or streaming by ability. Pupils at the compulsory level automatically move up from one grade to the next at the end of each year, with the weakest students getting remedial teaching provided by an extra teacher. Yet, the fact that decentralisation has not produced the same positive results as in Finland raises the question whether in Iceland all the pre-requisites are in place for such an approach to work. The counterpart to school autonomy needs to be increased accountability. Hence, adequate monitoring and evaluation mechanisms are crucial.

14. Current legislation stipulates that all compulsory schools are to adopt methods of evaluating their activities, including instruction and administrative practices. This is to provide information on factors such as quality control in operating schools, the educational achievement and careers of pupils, and teaching practices and their impact on educational outcomes. At five-year intervals, the internal evaluation procedures of schools are in turn subject to an evaluation by the national authorities. The results of the first round of this exercise were not very encouraging. $64 \%$ of the schools were found to have unsatisfactory self-evaluation procedures and another $20 \%$ to have partially satisfactory procedures (Ministry of Education, Science and Culture, 2004a). Schools have gradually become more positive towards internal evaluation. However, should the next round of evaluation of self-evaluation procedures not show significantly better results, more emphasis on external evaluations -- which can be carried out at the initiative of the Ministry of Education or upon a formal request from an outside party -- might be desirable, as well as increased transparency about the results and any follow-up. At the moment, it is up to the municipality and the school to decide whether and how they present the results of external evaluations to stakeholders, and the municipality is responsible for implementing any improvements. It is clear, though, that evaluators need to be trained and evaluated themselves and that adequate evaluation frameworks and tools need to be provided.

15. Another example is student assessment. In principle, examinations and other forms of assessment are carried out by individual teachers. Assessment is therefore not standardised between schools and teachers and the way in which reports on pupils' progress are compiled varies greatly. There are some nationally co-ordinated examinations that are composed, marked and organised by the Educational Testing Institute. In grades 4 and 7, pupils have to take such examinations in Icelandic and mathematics. At the end of the $10^{\text {th }}$ and final year of compulsory education pupils can sit examinations in a number of subjects. But 
this is no longer obligatory. Pupils can move to upper secondary education without such an examination (and regardless of their results in compulsory school, although there are different admission requirements to the different programmes of study). As noted, the result is that most of them start upper secondary education, but only to drop out of school in large numbers soon afterwards. An obligatory national examination at the end of compulsory schooling might provide an incentive for students to finish their studies, if they choose to do so, with better educational achievements than so far reported by the PISA surveys.

16. Finally, some measures that are envisaged in the context of the planned reduction of the duration of upper secondary education (see below) may also serve to improve educational achievements at the end of compulsory schooling. In particular, the educational content corresponding to the present first-year upper secondary courses in Icelandic, English, Danish and mathematics is to move down to compulsory schooling. This is considered to be feasible given the increase in class hours in the past decade. Care has to be taken, however, not to crowd out other essential subjects while providing adequate effective teaching time for the enhanced curriculum.

\section{Upper secondary education}

17. In stark contrast to developments at the compulsory level, expenditure pressures at the upper secondary level -- which is controlled and funded by the central government (except for a municipal contribution to school construction) -- have been well contained. The number of teachers has increased less than that of students, and the student/teacher ratio is not much different from the OECD average. Thus, the major issues at the upper secondary level are high drop-out rates entailing low attainment rates generally, and for vocational qualifications in particular. The authorities have tried to improve outcomes through performance management agreements with schools and by basing the funding of schools on the number of students taking examinations. Moreover, they have broadened the choice of subjects and striven to clarify study requirements. Nonetheless, adjustments of study materials and the educational content of instruction to some institutional changes since the mid-1990s (in particular the lengthening of the school year) have been lagging. Recently, reform efforts have focused on the duration of education, which is unusually long. As noted, Icelandic students complete their matriculation (university entrance) examination generally at the age of 20, whereas in most other countries students finish comparable programmes at the age of 18 or 19.

18. Discussions about a restructuring of the study programmes leading to the matriculation examination and ways of reducing their duration have been going on for a while. But before embarking on new fundamental reforms, it has been considered preferable to gather experience with the effects of the extension of compulsory schooling from 9 to 10 years in the early 1990s and the new national curriculum guidelines issued in the late 1990s. Reform efforts gathered momentum following a lengthy consultation process that culminated in the publication of a White Paper (Ministry of Education, Science and Culture, 2004b). The chances that the recommended reforms will be implemented have increased after the Ministry of Education and the Icelandic Teachers Union reached an agreement on the adjustment period given to schools for adapting to the revamped educational structure and a number of accompanying measures such as teacher re-training.

19. The centre-piece of the government's reform proposal is a shortening of the duration of upper secondary education from four to three years, as in the other countries of the European Economic Area and in accordance with the Bologna Agreement. This should allow young people to commence their university studies one year earlier and extend their working career and lifetime income. As an alternative, a shortening of compulsory education from ten to nine years was discussed but finally rejected (although it is not unusual in member countries), because it would oblige children in remote areas to leave home earlier and imply earlier selection, which is considered undesirable. The reform's impact on educational content would be limited by the transfer of some subject matter to the compulsory level, as noted above, and by the 
addition of five days of classes to each semester of upper secondary classes. Emphasis would be placed on schools retaining their flexibility and offering a variety of educational options. The restructuring of the system would provide the opportunity to re-examine national curricula, reorganise programmes and take other measures to further reduce dropout rates (such as reinforcing educational counselling). The challenge will be to implement the reduction of the length of studies leading to matriculation without weakening core competence achievement of graduates. This underlines the importance of enhancing educational quality by restructuring programmes and ensuring coherence across school levels. While it is true that the lengthening of the school year provides some scope for reducing the duration of schooling without lowering educational quality, net teaching hours are unusually low (the situation at the upper secondary level is not much different from that at the compulsory level described above). An alternative route would have been to encourage pupils to complete their studies faster, a possibility that exists but is rarely used (although an increasing number of female students take their matriculation examination already at the age of 19).

20. One of the more enduring challenges remains the issue of vocational and technical education which -- like in some other OECD countries -- suffers from a lack of parity of esteem, in particular at the upper secondary level. Although graduations in vocational programmes at the upper secondary level have picked up, they are not much above their previous peak in the second half of the 1990s. There is a shortage of skilled individuals in the service sector, and Icelandic experts consider that the share of upper secondary school students that opt for a vocational track ought to be more than twice as high as it currently is (OECD. 2006). In the context of the envisaged re-organisation of the school system, vocational and practical training is to be amplified, and participation in these types of education is to be encouraged by simplifying arrangements and increasing vocational counselling. Supplementary studies enabling students from vocational programmes to attain matriculation will continue to be offered. But the fact that the Ministry of Education had to declare expressly to universities that such upper secondary degrees are equivalent to others explains some of the difficulties in promoting the vocational track. Attitudes in society, and even in the school sector, towards general academic studies leading to matriculation strongly influence pupils' choice of programmes. In 2003/04, the last year for which statistics are available, the share of graduates with a vocational matriculation examination was only one-seventh. It is important that students graduating from vocational areas in secondary education find offers in higher education that match their interests within a well-developed vocationally-oriented sector at the tertiary level.

\section{The transformation of higher education}

21. Problems at the tertiary level are quite different. While the upper secondary level has been struggling to increase participation, the higher education sector has to cope with the consequences of an enormous expansion over the past decade or so, which has seen student numbers more than double. Enrolment of 20 to 29-year olds in tertiary education has reached one-third of this age group, which places Iceland fourth among OECD countries, and, in addition, enrolments by older people have increased substantially. The emergence of mass higher education and the fact that the sector has become more diverse -- with a strong increase in programmes and diplomas offered and a higher proportion of students enrolled in private institutions -- raise issues of funding and quality control. The following sections discuss, in turn, the legislative reform underway and the issues of tuition fees (not addressed by the reform) and foreign study of Icelanders (which has proportionally declined).

\section{Past and current reforms}

22. The 1997 Universities Act represented a watershed in the definition, organisation and governance of higher education, shifting the focus of policy to outcomes and the internal efficiency of institutions. The emphasis is now on attainment rather than access. All establishments are called upon to undertake research. At the same time, in order to introduce competitive elements in the system and thus enhance quality and efficiency, the sector has been opened to private parties. Moreover, institutions have been granted 
extensive autonomy. In return, they have been made more accountable and have to optimise their resource use. To this end, the authorities negotiate with them performance-related agreements (or service contracts in the case of private institutions, which entitles them to public funding). Some results of these reforms have been encouraging. A performance audit of the University of Iceland -- by far the largest in the country --found that the institution is run in a relatively cost-effective manner compared with equivalent European universities, given its high operating efficiency, while its performance in many areas of teaching and research is also fairly high (National Audit Office, 2005). More generally, however, there has been some concern that the number of graduates has not risen at the same pace as enrolments and that the tremendous rise in student numbers, along with the increased diversity of the system, might have adversely affected the quality of higher education. There is a clearly need to clarify the profile and specific role of new institutions in the higher education system and to strengthen the rather incipient system of institutional monitoring, quality assurance and accreditation.

23. New legislation governing higher education that is to enter into force on 1 July 2006 addresses such concerns. While no longer distinguishing between public and private institutions, the new law introduces more stringent criteria for recognition and quality control. The authorities will issue rules that stipulate the requirements which higher education institutions have to fulfil in order to achieve certification (including personnel qualification and an internal quality system). The certification -- which existing institutions will also have to seek -- will be limited to specific fields of study and can be revoked. The authorities will also issue a qualification framework regarding higher education (and diplomas listed in the law), and institutions will have to account for their compliance with the framework. Moreover, the new law defines the objectives and strengthens the existing rules regarding quality assurance of instruction and research, which are to be carried out both by internal evaluation and regular external evaluation. It stipulates explicitly that establishing mechanisms of internal quality assurance is a prerequisite for institutional certification. Finally, the legislation gives more leeway to the government regarding the funding of higher education institutions, but it leaves the authorisation to collect fees in state universities to special laws concerning each university.

\section{Tuition fees}

24. The strongly rising demand for higher education and the institutions' efforts to upgrade their post-graduate and research activities have put considerable fiscal pressure on the government. There are mechanisms in place to keep spending under control. The funding formula for teaching and facilities is based on the number of active, that is, full-time equivalent, students and not the number of enrolments. And the payment to an institution cannot exceed the budgeted level, which is based on the maximum number of full-time equivalents the government agrees to fund (and study categories). Still, the government's education spending is currently growing at double-digit rates and demographic developments suggest that fiscal pressures are likely to remain strong. Thus, both the government and the higher education institutions face some difficult choices. If the current rise in expenditure is deemed unsustainable, institutions -- that are now competing among themselves for funding, students and staff -might have to limit student intake to their teaching budget and develop their post-graduate programmes and research at a slower pace. And/or they would have to make further attempts to restrain costs and streamline operations, for instance by reducing or even discontinuing the teaching of certain subjects, further limiting students' access to some subjects, or stepping up student progress requirements. Finally, however, an assessment must be made as to whether public institutions' revenues cannot -- and should not -- be increased by complementing public funding with a student contribution.

25. There are economic incentives for individuals to contribute to the cost of higher education. A large and growing body of international evidence shows that those who acquire higher education qualifications enjoy considerable private benefits in terms of labour market outcomes. Although such benefits seem to be smaller than in many other countries, available Icelandic estimates of the private 
internal rate of return to higher education suggest that they are attractive, even in relation to the high real rate of interest prevailing in Iceland (Table 4). Another argument in favour of higher education fees is that they increase the responsiveness of institutions to the needs of students and can therefore be seen as important drivers for improving the quality of education. Furthermore, fees may assist in reducing the average duration of study, which is relatively long in Iceland. Another specific Icelandic feature is that private institutions receive state support to the same extent as the public institutions and can also charge tuition fees (which account for one-third of their revenue), whereas public institutions are only authorised to charge registration fees (which are minor). This distorts competition in various fields of study. Equity concerns that are often expressed can be addressed by the use of student loans. A student loan scheme already exists and is relatively large in relation to GDP by international comparison. It provides students with index-linked loans at a $1 \%$ interest rate. Repayment starts two years after the completion of studies and its speed depends on the person's income. This scheme could be improved in some ways. For instance, it currently penalises self-reliance since the amount a student can borrow depends on his/her previous year's income; students can draw on their loans only at the end of each semester and may find themselves obliged to take out commercial loans meanwhile; and its study requirements de-bar most part-time students from the scheme (OECD. 2006). The experience of countries that have combined an increase in education fees with an improvement in student loan facilities suggests that there are no significant adverse effects on participation (Blondal et al., 2002).

Table 4. Returns to education

2003

\begin{tabular}{lc|r}
\hline & Males & Females \\
\hline Private rate of return on higher education & 5.0 & 10.8 \\
Social rate of return on higher education & 5.6 & 9.8 \\
\hline Private rate of return on upper secondary education & 7.2 & 4.2 \\
Social rate of return on upper secondary education & 7.9 & 4.7 \\
\hline
\end{tabular}

Note: Figures calculated according to OECD standards as published in Education at a Glance 2001.

Source: Institute of Economic Studies, University of Iceland.

\section{Internationalisation}

26. Given the geographically peripheral nature and small population of the country, higher education in Iceland has always had a strong international dimension in the form of cross-frontier studies. The recent rapid expansion of the tertiary system has "repatriated" higher education -- brought it home -- in the sense that the proportion of those studying abroad has declined sharply (OECD, 2006). While in 1988, the year when the highest number of students was enrolled at foreign universities, their share was around one-third, the number of wandering scholars as a proportion of all Icelandic students has now dropped to one-seventh (Figure 6). Special factors -- such as the marked decline in those studying in the United States in recent years -- have played a role, but the impact of the growth in the home system is evident (Jonasson, 2004). It has been pointed out that the proportion of Icelanders studying abroad is still above the $10 \%$ objective of the original ERASMUS programme. Also, OECD figures that are obtained from the countries of destination rather than the Icelandic student loan fund show a somewhat higher ratio. Still, on present trends, students seeking education abroad will soon be a small minority. 
Figure 6. Icelandic students at the tertiary level at home and abroad

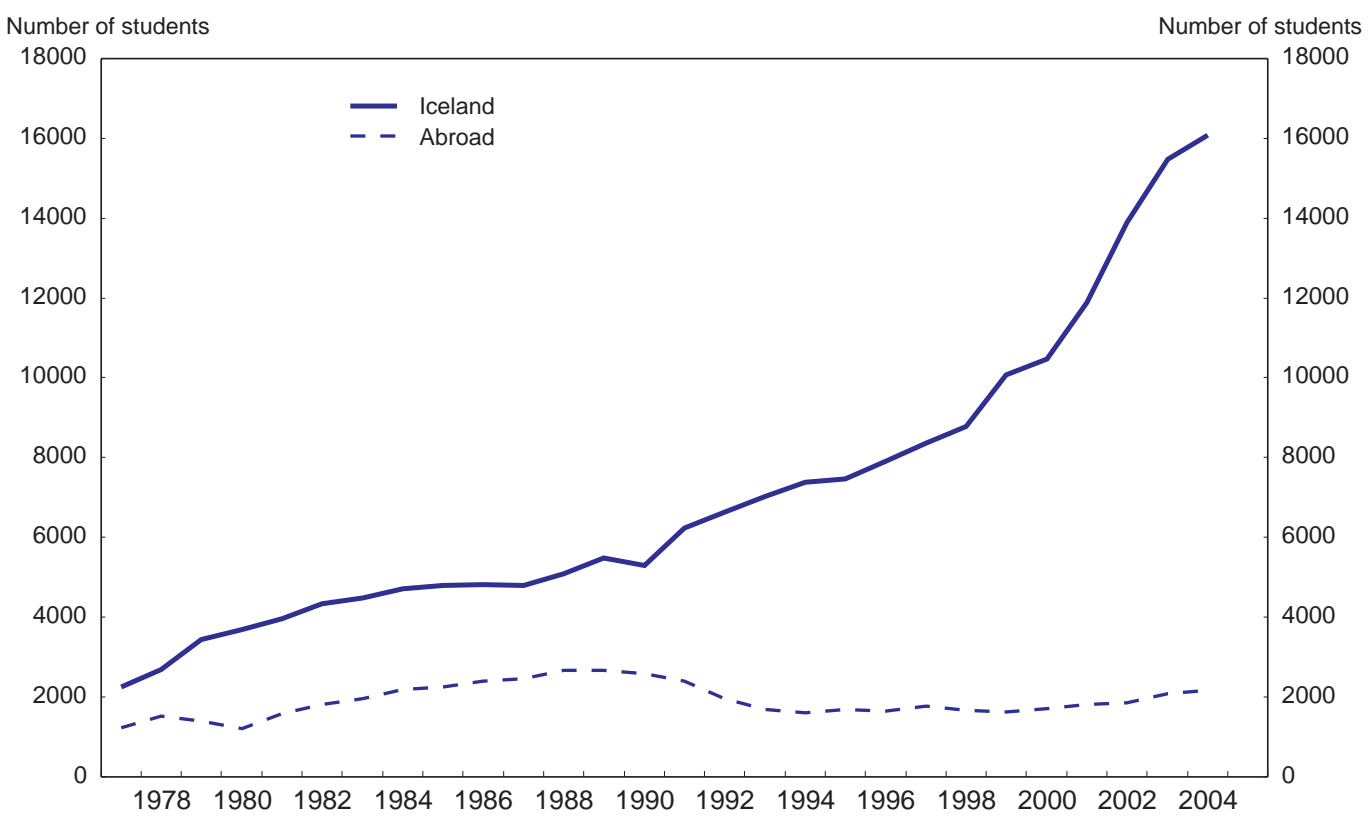

Source: Statistics Iceland.

27. Student mobility is particularly important to reinforce Iceland's research capacity and drive towards a knowledge economy. In this perspective, what matters most is that international ties continue at the graduate and doctoral stage (OECD, 2006). Unfortunately, available information suggests that the general trend described above is not limited to undergraduates. The development of higher education in Iceland towards a more and more comprehensive system has clearly adversely affected student mobility. In this context, the question arises whether the country, with its small population, should try and offer high quality programmes in all disciplines and fields. It would seem to be obvious that this is difficult, if not impossible, for the highest academic degree programmes. Many postgraduate programmes have already been organised with the intention of allowing students to take part of their courses abroad. This approach should be generalised. The public student loan fund does not discriminate against graduate students who study outside the country, which is welcome. But at the undergraduate level, loans to pay tuition fees abroad are not provided if a similar programme is available in Iceland. The government may want to review this restriction in the context of a possible introduction of tuition fees in public institutions. Obviously, for investment in "students abroad" to be successful, most of them will in the end have to return to Iceland. This seems to be largely the case, but it would be helpful if it could be confirmed by data that are not just based on anecdotal evidence.

\section{Concluding remarks}

28. Like the country more generally, Iceland's education system has undergone radical changes over the past decade or so. Despite the reforms and strongly increased public funding, Iceland's performance in generating a skilled labour force is not yet satisfactory, with no improvement in educational achievements at the end of compulsory schooling and a persistent gap between low skilled and highly skilled in the labour force. At the same time, higher education is struggling to maintain quality standards in the face of a strong student inflow. Some recommendations on how to improve outcomes are provided in Box 1. 


\section{Box 1. Recommendations regarding human resource development}

\section{Compulsory education}

The devolution of responsibility for compulsory education to the municipalities is largely in line with emerging "best practices" in the OECD. But in Iceland it has not been an unmitigated success so far. While per student spending has increased strongly, educational achievements as measured by literacy and numeracy tests have on average stagnated. And the strong expansion in the teaching staff has not been accompanied by a rise in average qualification. Some adjustments may therefore be warranted.

- $\quad$ Strengthen evaluation procedures in schools to assure that, where posts are filled by unlicensed teachers, job performance is nonetheless up to standards.

- More generally, focus on teacher quality rather than quantity and increase class size to reduce cost pressures.

- Re-enforce central government quality control if schools' self-evaluation procedures continue to remain unsatisfactory.

- Increase the effective teaching time to accommodate the planned transfer of subject matter from the upper secondary to the lower secondary school level.

\section{Upper secondary education}

Despite rising enrolment, upper secondary attainment is unsatisfactory because of high drop-out rates. Planned reforms will reduce the duration of upper secondary education, which is long by international comparison, by one year while lengthening the school year somewhat.

- Make sure that the reduction in the length of upper secondary education is matched by increasing effective teaching time and appropriate curriculum adjustment so that core competence achievement of graduates is not substantially weakened.

- $\quad$ Encourage high performance students to complete both lower and upper secondary education ahead of schedule, making use of existing flexibility in the system.

- Encourage potential drop-outs to select vocational programmes through increased counseling, a broader choice of programmes and re-enforced "bridges" from upper secondary vocational tracks into tertiary education.

\section{Higher education}

The explosion of tertiary enrolment over the past decade has led to spending pressures and risks affecting the quality of higher education. Legislative changes address these problems to some extent. The rapid expansion of the higher education sector and development of a more comprehensive system has crowded out -- traditionally frequent -studies abroad.

- Implement quickly the new legislation that aims to ensure educational quality by stricter certification and evaluation requirements for higher education institutions.

- Introduce tuition fees for public institutions, given that private returns to higher education are substantial. This would tend to make institutions more responsive to student needs, encourage students to complete studies more quickly and provide a much needed source of finance. At the same time, student loan facilities could be improved.

- Instead of trying to offer a full range of tertiary programmes, encourage studies abroad, in particular at the graduate and doctoral stages of university education. 
ECO/WKP(2006)44

\section{Annex 1}

\section{PISA results for Iceland}

1. The OECD's Programme for International Student Assessment (PISA) assesses student knowledge and skills in mathematics, science, reading and cross-curricular competencies at age 15 , that is towards the end of compulsory education. The 2003 round of PISA focused on mathematics, with less testing time devoted to reading, science and problem solving. PISA assesses students' ability to reflect on their knowledge and experience in these areas and to apply them to real world issues (literacy concept). It includes questions regarding student socio-economic and psychological characteristics, school resources and teaching environment, and education system characteristics. In principle, PISA uses non-random sampling to select students for test, but in the case of Iceland -- given the size of the population -- the sample covers all 15-year olds.

2. Instead of estimating individual equations for scores in each of the four test fields, the analysis of the PISA 2003 data below summarises information regarding student performance by the first principal component of the test scores in mathematics, reading, science and problem solving. This can be justified on the grounds that the interest of the analysis lies with the overall design of the school system and students' success within this system independent of their field of excellence. Moreover, the first component captures 85-90\% of the total variance across test fields. The estimations control for the fact that students from the same school are likely to have similar test results. A detailed description of the estimation methodology can be found in Annex 4.A2 of the 2006 Economic Survey of Luxembourg.

3. Table A1 shows the results of the baseline equation, which includes the variables found to be most relevant for Iceland, that is, gender (one for a girl, two for boy) and the student's socio-economic background as measured by the highest occupational status of parents (educational background and resources at student's home provide similar results). There is no control for grade or age because this is not relevant in the case of Iceland since there is hardly any difference for students in these respects. As can be seen from the Table, even when controlling for the socio-economic background, an immigration status or a language spoken at home that is different from either the official or the test language both have a significant (negative) impact on test results, but not jointly. 
Table A1. Immigration and language

\begin{tabular}{lrrrr}
\hline & Baseline & \multicolumn{3}{c}{ Immigration and language } \\
\cline { 2 - 5 } & & $\mathrm{A}$ & $\mathrm{B}$ & $\mathrm{C}$ \\
\cline { 2 - 5 } Gender & $\begin{array}{r}-0.592^{\star \star \star} \\
(-6.55)\end{array}$ & $\begin{array}{r}-0.584^{\star \star \star} \\
(-6.52)\end{array}$ & $\begin{array}{r}-0.583^{\star \star \star} \\
(-6.38)\end{array}$ & $\begin{array}{r}-0.574^{\star \star \star} \\
(-6.34)\end{array}$ \\
Parents' occupational status & $\begin{array}{r}0.018^{\star \star \star} \\
(8.06)\end{array}$ & $\begin{array}{r}(8.11) \\
0.613^{\star \star \star}\end{array}$ & $\begin{array}{r}0.019^{\star \star \star} \\
(8.11)\end{array}$ & $\begin{array}{r}0.019^{\star \star \star} \\
(8.24)\end{array}$ \\
Immigration status & & $(-3.11)$ & & -0.389 \\
Language spoken at home & & & $-0.857^{\star \star \star}$ & $(-1.57)$ \\
& & & $(-2.46)$ & -0.515 \\
Number of observations & 3273 & 3241 & 3220 & 3188 \\
R square & 0.05 & 0.06 & 0.06 & 0.06 \\
\hline
\end{tabular}

Note: t-Statistics in parentheses. Significance levels are indicated by asterisks: ***: $1 \%$ level, **: $5 \%$ level, *: $10 \%$ level.

Source: PISA 2003, Secretariat calculations.

4. Adding indicators of educational quality to the baseline equation does not improve the results. Variables such as the quality of physical and educational infrastructure (buildings, library and instruction materials), the proportion of certified teachers and computer availability have no additional significant impact on test scores (Table A2). By contrast, school climate indicators (student/teacher relations, attitude towards school, teacher support and disciplinary classroom climate) are significant when included in the baseline equation (Table A3). Contrary to computer facilities at school, computer facilities at home (computer, software, internet access) are in general favourable to test scores. However, the use made of them is important: education-related use improves scores, while unrelated use (such as internet use to download music) does not (Table 5.A4).

Table A2. School educational resources

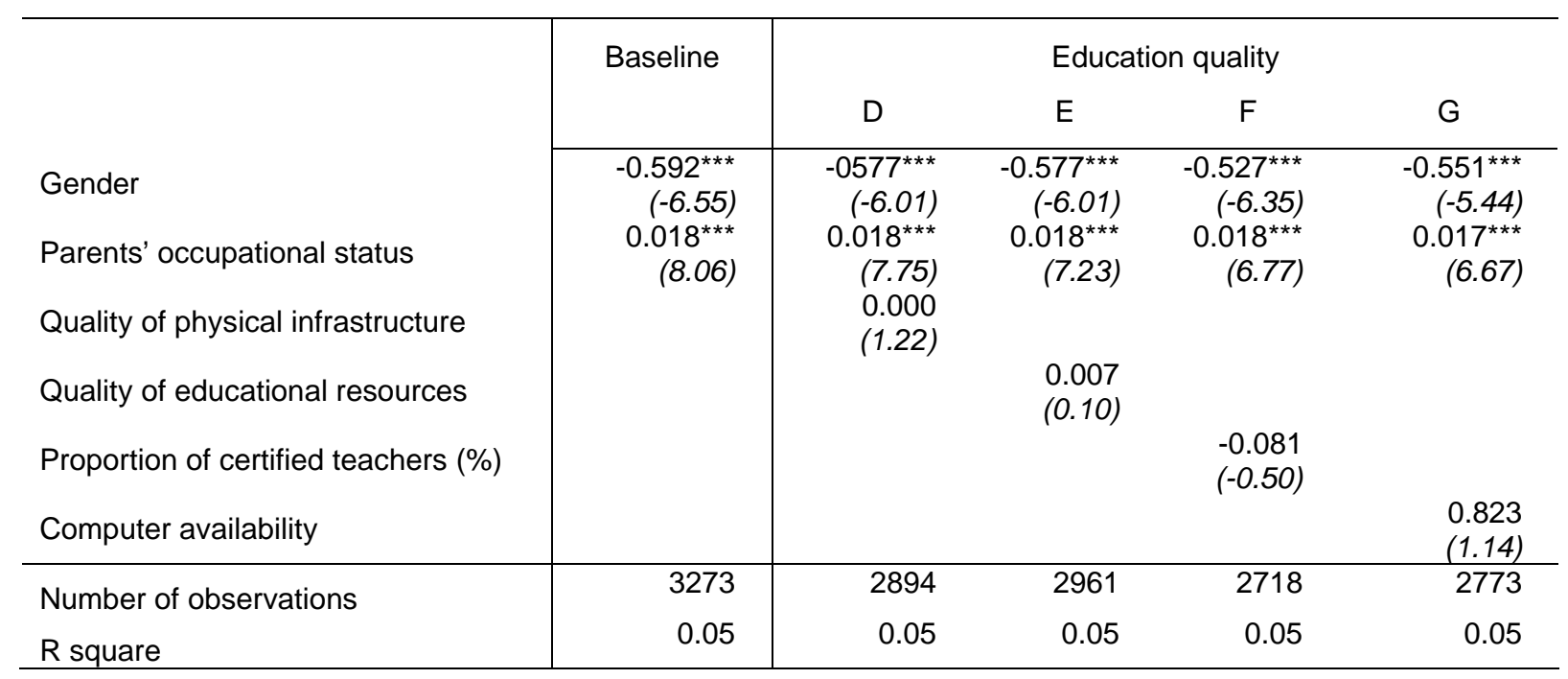

Note: t-Statistics in parentheses. Significance levels are indicated by asterisks: **: $1 \%$ level, **: $5 \%$ level, *: 10\% level.

Source: PISA 2003, Secretariat calculations. 
Table A3. School climate

\begin{tabular}{|c|c|c|c|c|c|}
\hline & \multirow[t]{2}{*}{ Baseline } & \multicolumn{4}{|c|}{ School climate } \\
\hline & & $\mathrm{H}$ & 1 & $\mathrm{~J}$ & $\mathrm{~K}$ \\
\hline Gender & $\begin{array}{c}-0.592^{\star \star \star} \\
(-6.55)\end{array}$ & $\begin{array}{c}-0.535^{\star \star \star} \\
(-6.18)\end{array}$ & $\begin{array}{c}-0.489 * \star \star \\
(-5.79)\end{array}$ & $\begin{array}{c}-0.550 * \star \star \\
(-6.47)\end{array}$ & 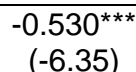 \\
\hline Parents' occupational status & $\begin{array}{c}0.018^{\star \star \star} \\
(8.06)\end{array}$ & $\begin{array}{c}0.018^{\star \star \star} \\
(7.71)\end{array}$ & $\begin{array}{c}0.017^{\star \star \star} \\
(7.60)\end{array}$ & $\begin{array}{c}0.018^{\star \star *} \\
(8.00)\end{array}$ & $\begin{array}{c}0.018^{\star \star \star} \\
(7.89)\end{array}$ \\
\hline Student-teacher relations & & $\begin{array}{c}0.260^{\star \star *} \\
(7.97)\end{array}$ & & & \\
\hline Attitude toward school & & & $\begin{array}{c}0.302^{\star \star \star} \\
(9.40)\end{array}$ & & \\
\hline Teacher support & & & & $\begin{array}{c}-0.220^{\star \star \star *} \\
(5.25)\end{array}$ & \\
\hline Disciplinary classroom climate & & & & & $\begin{array}{c}0.248^{\star * *} \\
(5.08)\end{array}$ \\
\hline Number of observations & 3273 & 3264 & 3261 & 3243 & 3242 \\
\hline R square & 0.05 & 0.08 & 0.08 & 0.06 & 0.06 \\
\hline
\end{tabular}

Note: t-Statistics in parentheses. Significance levels are indicated by asterisks: **: $1 \%$ level, **: $5 \%$ level, *: 10\% level.

Source: PISA 2003, Secretariat calculations.

Table A4. Use of computer

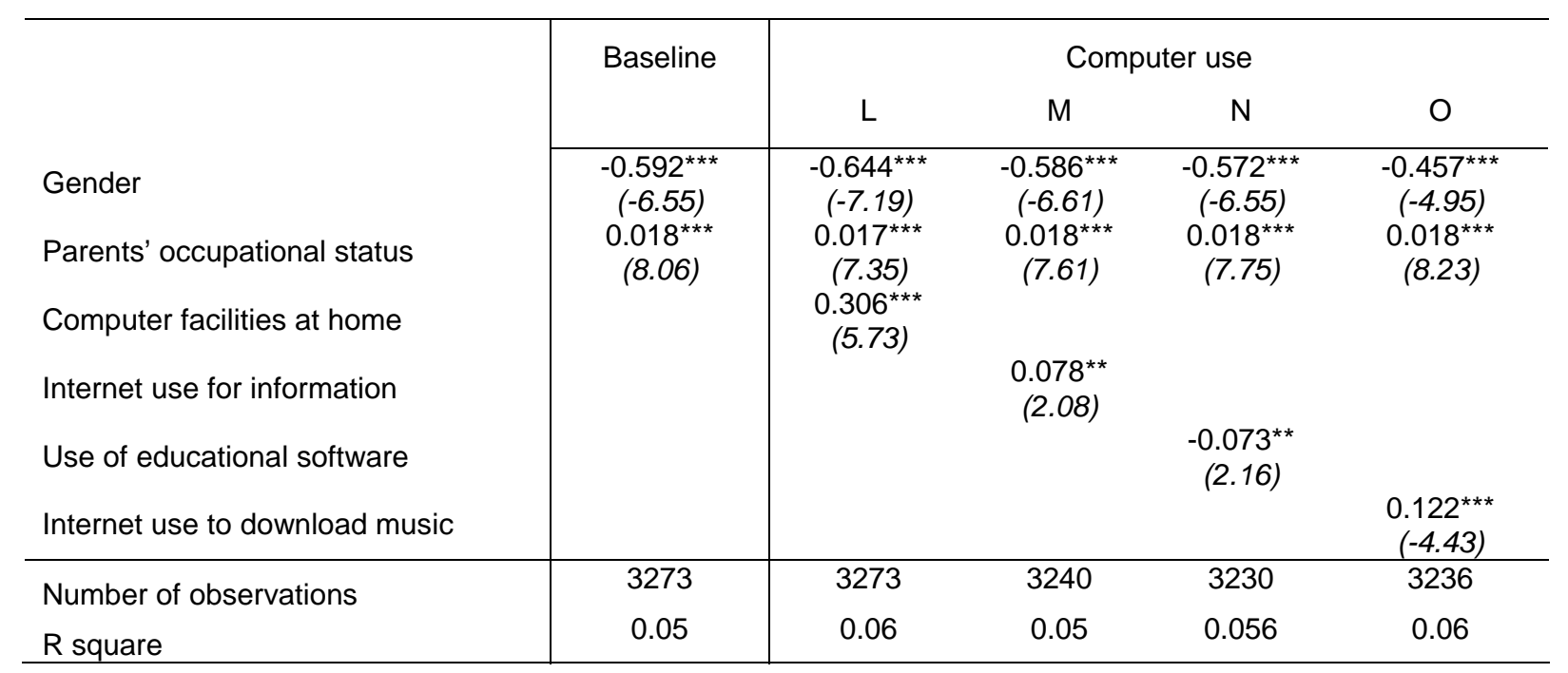

Note: t-Statistics in parentheses. Significance levels are indicated by asterisks: ***: $1 \%$ level, $* *$ : $5 \%$ level, *: $10 \%$ level.

Source: PISA 2003, Secretariat calculations.

5. Finally, when retaining the initially significant variables to test their joint impact on the PISA 2003 scores, the baseline variables (gender and socio-economic background), immigration status, school climate and computer facilities at home all have a significant impact, while school infrastructure (in particular computer resources at school) still do not play a significant role. Yet, although the joint impact equation improves the results of the baseline equation, its explanatory value is relatively limited (Table A5). 
Table A5. Joint Impact

\begin{tabular}{|c|c|c|c|}
\hline & Baseline & \multicolumn{2}{|c|}{ Joint Impact } \\
\hline & & $\mathrm{P}$ & $\mathrm{Q}$ \\
\hline Gender & $-0.592^{\star \star \star}$ & $\begin{array}{l}-0.573^{\star \star \star} \\
\left(-6^{*}\right.\end{array}$ & $-0.538^{\star \star \star}$ \\
\hline & $0.018^{\star \star \star}$ & $0.017^{\star \star \star}$ & $0.016^{\star \star \star}$ \\
\hline Parents' occupational status & $(8.06)$ & $(7.09)$ & $(5.85)$ \\
\hline Immigration status & & $0.633^{\star \star \star}$ & $-0.698^{\star \star \star}$ \\
\hline Computer availability & & & 0.655 \\
\hline Student-teacher relations & & $0.245^{\star \star \star}$ & $0.260^{\star \star \star}$ \\
\hline & & $\begin{array}{c}(1.55) \\
0.250^{\star \star \star} \\
(4.87)\end{array}$ & $\begin{array}{c}(1.43) \\
-0.261^{\star \star \star} \\
(4.49)\end{array}$ \\
\hline Number of observations & 3273 & 3233 & 2735 \\
\hline $\mathrm{R}$ square & 0.05 & 0.09 & 0.09 \\
\hline
\end{tabular}

Note: t-Statistics in parentheses. Significance levels are indicated by asterisks: ***: 1\% level, **: $5 \%$ level, *: $10 \%$ level.

Source: PISA 2003, Secretariat calculations.

\section{Bibliography}

Blondal, S., S. Field and N. Girourard (2002), "Investment in Human Capital through Upper Secondary and Tertiary Education”, OECD Economic Studies, No. 34, Paris.

Coulombe, S., J.F. Tremblay and S. Marchand (2004), Literacy Scores, Human Capital and Growth Across Fourteen OECD Countries, Statistics Canada, Ottawa.

Jonasson, J.T. (2004), "Higher education reforms in Iceland at the transition to the twenty-first century", in I. Fargelind and G. Stromquist (Eds.), Reforming Higher Education in the Nordic Countries. Studies of Change in Denmark, finland, Iceland, Norway and Sweden, International Institute for Educational Planning, Paris.

Ministry of Education, Science and Culture (2004a), Findings of evaluation of self-evaluation procedures in primary/lower secondary schools 2001-2003, Reykjavik, April.

Ministry of Education, Science and Culture (2004b), New Educational Structuring for Matriculation Studies - A Furthering of Continuity in School Activities, Reykjavik, August.

Ministry of Education, Science and Culture (2005), OECD Thematic Review of Tertiary Education. National Background Report for Iceland, Reykjavik, September. 
National Audit Office (2005), The University of Iceland: Performance Audit, Reykjavik, April.

OECD (1997), OECD Economic Surveys. Iceland, Paris, May.

OECD (2001), Knowledge and Skills for Life. First results from PISA 2000, Paris.

OECD (2004), Learning for Tomorrow's World. First Results from PISA 2003, Paris.

OECD (2005a), Education at a Glance. OECD Indicators 2005, Paris.

OECD (2005b), Are Students Ready for a Technology-Rich World? What PISA Studies Tell Us, Paris.

OECD (2005c), School factors Related to Quality and Equity. Results from PISA 2000, Paris.

OECD (2005d), Teachers Matter. Attracting, Developing and Retaining Effective Teachers, Paris.

OECD (2006), Thematic Review of Tertiary Education. Iceland Country Note, Paris, forthcoming.

Olafsson. R.F., A.M. Haldorsson and J.K. Bjornsson (2006), Gender and the Urban-Rural Differences in Mathematics and Reading: An Overview of PISA 2003 Results in Iceland, Educational Testing Institute, Reykjavik.

Schleicher, A. (2006), The economics of knowledge: Why education is key for Europe's success, Lisbon Council Policy Brief, Brussels. 


\section{WORKING PAPERS}

The full series of Economics Department Working Papers can be consulted at www.oecd.org/eco/Working Papers/

514. Finland's housing market: reducing risks and improving policies (September 2006) Laura Vartia

513. The Danish housing market: Less subsidy and more flexibility (September 2006) Espen Erlandsen, Jens Lundsgaard and Felix Huefner

512. Labour market reform in Germany: How to improve effectiveness (September 2006) Eckhard Wurzel

511. Removing obstacles to employment for women in Ireland (September 2006) Boris Cournède

510. Assessing Russia's non-fuel trade elasticities: Does the Russian economy react "normally" to exchange rate movements?

(September 2006) Christian Gianella and Corinne Chanteloup

509. Regulation, competition and productivity convergence (September 2006) Paul Conway, Donato De Rosa, Giuseppe Nicoletti and Faye Steiner

508. Improving education achievement and attainment in Luxembourg to compete in the labour market (September 2006) David Carey and Ekkehard Ernst

507. Raising economic performance by fostering product market competition in Germany (August 2006) Andrés Fuentes, Eckhard Wurzel and Andreas Reindl

506. Regulation of financial systems and economic growth (August 2006) Alain de Serres, Shuji Kobayakawa, Torsten Sløk and Laura Vartia

505. Enhancing Portugal's human capital

(August 2006) Bénédicte Larre and Stéphanie Guichard

504. Improving labour market performance in France Améliorer la performance du marché du travail en France (July 2006) Stéphanie Jamet

503. Wage setting in Finland: Increasing flexibility in centralised wage agreements (July 2006) Åsa Johansson

502. Taxation, business environment and FDI location in OECD countries (July 2006) Dana Hajkova, Giuseppe Nicoletti, Laura Vartia and Kwang-Yeol Yoo

501. The political economy of structural reform: Empirical evidence from OECD countries (July 2006) Jens Høj, Vincenzo Galasso, Giuseppe Nicoletti and Thai-Thanh Dang

500. Labour market performance, income inequality and poverty in OECD countries (July 2006) Jean-Marc Burniaux, Flavio Padrini and Nicola Brandt

499. Improving Public-Spending Efficiency in Czech Regions and Municipalities (July 2006) Philip Hemmings

498. Policies to Promote Innovation in the Czech Republic (July 2006) Alessandro Goglio 
497. Getting Education Right for Long-Term Growth in the Czech Republic (July 2006) Alessandro Goglio

496. Assessing the 2005 Czech Proposals for Pension Reform (July 2006) Philip Hemmings and Edward Whitehouse

495. Poland's Education and Training: Boosting and Adapting Human Capital (July 2006) Paul O’Brien and Wojciech Paczynski

494. The Rates and Revenue of Bank Transaction Taxes (July 2006) Jorge Baca-Campodónico, Luiz de Mello and Andrei Kirilenko

493. Nothing Ventured, Nothing Gained: The Long-Run Fiscal Reward of Structural Reforms (July 2006) Peter Hoeller and Claude Giorno

492. Ireland's Housing Boom: What has Driven It and Have Prices Overshot? (June 2006) Dave Rae and Paul van den Noord

491. Boosting Competition in Ireland (June 2006) Dave Rae, Line Vogt and Michael Wise

490. Factors Behind Low Long-Term Interest Rates (June 2006) Rudiger Ahrend, Pietro Catte and Robert Price

489. The Fiscal Challenge in Portugal (June 2006) Stéphanie Guichard and Willi Leibfritz

488. Are House Prices Nearing a Peak? A Probit Analysis for 17 OECD Countries (June 2006) Paul van den Noord

487. Maintaining Switzerland's Top Innovation Capacity (June 2006) Florence Jaumotte

486. Employment Patterns in OECD Countries: Reassessing the Role of Policies and Institutions (June 2006) Andrea Bassanini and Romain Duval

485. Brazil’s Fiscal Stance During 1995-2005: The Effect of Indebtedness on Fiscal Policy Over the Business Cycle

(May 2006) Luiz de Mello and Diego Moccero

484. Realising the Oil Supply Potential of the CIS: The Impact of Institutions and Policies (May 2006) Rudiger Ahrend and William Tompson

483. Summary of a workshop on global convergence scenarios: structural and policy issues (May 2006) Nick Vanston

482. Revised OECD methods for supply-side and medium-term assessment: a capital services approach (July) Pierre-Olivier Beffy, Patrice Ollivaud, Pete Richardson and Frank Sédillot

481. Balancing health care quality and cost containment: the case of Norway (February 2006) Alexandra Bibbee and Flavio Padrini

480. The ageing challenge in Norway: ensuring a sustainable pension and welfare system (February 2006) Benoît Bellone and Alexandra Bibbee 